\title{
ANALISIS LOGAM BERAT (Mn, Fe, Cd), SIANIDA DAN NITRIT PADA AIR ASAM TAMBANG BATU BARA
}

\author{
Kiswanto $^{1}$, Wintah ${ }^{2}$, Nur Laila Rahayu ${ }^{3}$ \\ ${ }^{1}$ Fakultas Teknik Industri Universitas Teuku Umar Meulaboh \\ ${ }^{2}$ Fakultas Kesehatan Masyarakat Universitas Teuku Umar Meulaboh \\ ${ }^{3}$ Fakultas Sains dan Teknologi Universitas Nahdhatul Ulama Purwokerto \\ Korespondensi: kiswanto@utu.ac.id
}

\begin{abstract}
Coal mining of PT. Mifa Brothers in Aceh Barat produces liquid waste containing hazardous heavy metals. Research conducted at PT. Mifa Brothers located in Sumber Batu Village, Meureubo Subdistrict, West Aceh Regency, Aceh Province. The coal mining activities by the PT. Mifa Brothers used open-cast mining systems with open method. From the resulting liquid waste, the PT. Mifa Brothers made two ponds used as liquid waste treatment. Efficiency of Sewage Treatment Plant (STP or IPAL) conducted by the industry, can be known through the analysis of heavy metals content ( $\mathrm{Fe}, \mathrm{Mn}$ and $\mathrm{Cd}$ ), cyanide and nitrite on inlet and outlet of liquid waste shelter. This analysis was determined using the atomic absorption Spectropotemer (SSA) for metal Fe, Mn and $\mathrm{Cd}$, while $\mathrm{CN}$-and $\mathrm{NO}_{2}$-analysis-using $\mathrm{UV}$-Vis spectrophotometry methods. Test result of heavy metal ions of iron ion, manganese ions, cadmium ions, nitrite, and cyanide on each inlet is 8.24; 0.223 ; $<0.01 ; 0.034 \mathrm{mg} / \mathrm{L}$ and 0.321 on each outlet are $3.03 ; 0.189 ;<0.01 \mathrm{mg} / \mathrm{L} ; 0.016$ and undetectable for cyanide. Sewage treatment at PT. Mifa Brothers using Dolomite method as adsorbent has not been efficient and efficient in the reduction of pollutant levels.
\end{abstract}

Keywords : SSA, UV-Vis spectrophotometry, Inlet and outlet, $\mathrm{Fe}, \mathrm{Mn}, \mathrm{Cd}, \mathrm{NO}_{2}, \mathrm{CN}^{-}$

\section{PENDAHULUAN}

Aceh Barat merupakan satu-satunya Kabupaten di Provinsi Aceh yang memiliki cadangan batu bara cukup besar. Berdasarkan data dari Kementerian Energi dan Sumber Daya Mineral (2012), Kabupaten Aceh Barat memiliki potensi cadangan sumber daya batu bara sebesar 1,7 milyar ton dengan sumber daya batu bara yang telah diketahui sebesar 600 juta ton dan total cadangan sebesar 400 juta ton.

Sekarang ini sumber daya batu bara telah dilakukan penambangan oleh PT Mifa Bersaudara dengan penambangan percobaan (pilot mining) sejak Januari 2012 dan telah mengapalkan batu bara ke Lhok Nga, Aceh Besar sejak Oktober 2012. Dengan demikian, PT Mifa Bersaudara merupakan industri batu bara pertama kali di Aceh dengan pengiriman tongkang perdananya. Perusahaan ini telah mendapatkan pengakuan Eksportir Terdaftar (ET Batu bara) No. 03.ET-04.14.0072 dan telah memulai ekspor sejak Januari 2015. Perusahaan telah membangun infrastruktur dari mulai fasilitas operasional tambang, pemecah batu bara (coal crushing plant), jalan angkut khusus batu bara, sampai dengan sistem pemuatan batu bara curah ke tongkang di Pantai Peunaga, Aceh Barat yang lebih dikenal dengan terminal khusus batu bara PT Mifa Bersaudara, serta fasilitas pendukung lainnya.

Seiring meningkatnya devisa ekonomi, dampak negatif dari pertambangan juga tidak bisa dihindari, terutama dampak terhadap lingkungan hidup. Masyarakat di sekitar area konsesi PT. Mifa Bersaudara, menyatakan keluhan tentang pencemaran terhadap lingkungan dan air sungai yang akhir-akhir ini semakin keruh. Penambangan batu bara secara langsung menyebabkan pencemaran air, yaitu dari limbah pencucian batu bara tersebut, yang memisahkan batu bara dengan sulfur. Limbah pencucian tersebut mencemari air sungai, sehingga warna air menjadi keruh, asam, dan menyebabkan pendangkalan sungai akibat endapan pencucian batu bara tersebut.

Limbah cair asam batu bara yang dihasilkan dari proses pencucian batu bara 
diduga mengandung logam berat berbahaya. Unsur-unsur dan senyawa kimia logam berat besi, mangan dan kadmium ini berasal dari tanah dan batuan yang ikut terbawa pada saat proses eksploitasi batu bara. Meskipun pihak industri sudah melakukan tindakan dalam pengendalian tingkat cemaran berupa kolam penampungan limbah cair dengan perlakuan penambahan dolomit sebagai mineral penetral dan adsorben, namun hasilnya belum optimum.

Kegiatan penambangan batu bara yang terdapat di Desa Sumber Batu Kecamatan Meureubo Kabupaten Aceh Barat berdampak pada air permukaan sungai. Kadar logam berat Besi (Fe), Mangan (Mn), dan Kadmium (Cd) pada badan sungai telah melebihi nilai ambang batas yang diperbolehkan pada PP No. 82 Tahun 2001 yaitu: Fe sebesar 0,3 ppm, Mn sebesar 0,0440 ppm, dan Cd sebesar 0,1195 ppm. Tingginya kandungan logam Fe, Mn dan $\mathrm{Cd}$ tidak menutup kemungkinan adanya kandungan logam lain.

Tujuan penelitian untuk mengetahui kandungan logam berat ( $\mathrm{Fe}, \mathrm{Mn}$ dan $\mathrm{Cd}$ ), sianida dan nitrit menggunakan bahan penetral dolomit kapur pada kolam tambang batu bara PT. Mifa Bersaudara di Aceh Barat. Metode penelitian ini bersifat eksperimen eks situ dan in-situ. Kandungan logam berat $\mathrm{Fe}, \mathrm{Mn}$, dan $\mathrm{Cd}$ dianalisis dengan metoda Spektrofotometri Serapan Atom. Untuk analisis sianida dan nitrit menggunakan Spektrofotomet UV-Vis.

\section{TINJAUAN PUSTAKA}

\subsection{Air Asam Tambang}

Air asam tambang (AAT) atau dalam bahasa asing acid mine drainage (AMD), atau acid rock drainage (ARD) merupakan limbah cair yang dapat menyebabkan pencemaran pada air permukaan. Dalam industri pertambangan batu bara disebut dengan coal mine drainage (CMD). Air asam tambang terbentuk akibat kegiatan pertambangan terbuka maupun tertutup (bawah tanah), dalam prosesnya terjadi reaksi antara air, oksigen, dan batuan-batuanyang mengandung mineralmineral sulfida sehingga menyebabkan air asam.

\subsection{Sumber-sumber Air Asam Tambang}

Air asam tambang batu bara terjadi karena kegiatan penambangan baik itu tambang terbuka maupun tambang dalam, umumnya keadaan ini terjadi karena unsur sulfur yang terdapat di dalam batuan teroksidasi secara alamiah didukung juga dengan curah hujan yang tinggi semakin mempercepat perubahan oksida sulfur menjadi asam. Sumber-sumber air asam tambang batu bara berasal dari aktivitas sebagai berikut:

1. Air dari tambang terbuka

2. Air dari unit pengolahan limbah tailing

3. Air dari pengolahan batuan buangan

4. Air dari lokasi penimbunan batuan

\subsection{Kandungan pencemar pada air asam} tambang batu bara

Industri pertambangan batu bara terbuka banyak bahan pencemar khususnya, kandungan logam berat dan beberapa senyawa toksik. Dalam Keputusan Menteri Negara Lingkungan Hidup Nomor 113 Tahun 2003 yaitu besi dan mangan. Selain itu dalam kandungan batu bara juga terdapat logam berat kadmium, sianinda dan nitrit yang bersifat toksik terhadap lingkungan pada air permukaan.

\section{Besi (Fe)}

Keberadaan besi pada kerak bumi menempati posisi keempat terbesar. Besi ditemukan dalam bentuk kation ferro $\left(\mathrm{Fe}^{2+}\right)$ dan ferri $\left(\mathrm{Fe}^{3+}\right)$. Pada perairan alami dengan $\mathrm{pH}$ sekitar 7 dan kadar oksigen terlarut yang cukup, ion ferro bersifat mudah larut dioksidasi menjadi ion ferri. Pada oksidasi ini terjadi pelepasan elektron. Pada reduksi ferri menjadi ferro terjadi penangkapan elektron. Menurut Efendi dalam Kiswanto (2018), bahwa kadar besi yang berlebihan dapat menghambat fiksasi unsur lainnya.

2. Mangan (Mn)

Mangan adalah kation logam yang memiliki karakteristik kimia serupa dengan besi. Mangan berada dalam bentuk manganous $\left(\mathrm{Mn}^{2+}\right)$ dan manganik $\left(\mathrm{Mn}^{3+}\right)$. Konsentrasi mangan yang lebih tinggi dapat ditemukan di perairan dengan tingkat $\mathrm{pH}$ rendah (Dimkic, Heinz dan michael, 2008) 
3. Cadmium (Cd)

Kadmium (Cd) merupakan metal berbentuk kristal putih keperakan. Kadmium ditemukan bersama-sama dengan unsur $\mathrm{Zn}$, $\mathrm{Cu}$, dan $\mathrm{Pb}$ dalam jumlah yang kecil. Kadmium ditemukan pada industri alloy, pemurnian Zn, pestisida, dan lain-lain (Said, N.I, 2005). Manusia di dalam tubuhnya tidak memerlukan kadmium dalam fungsi pertumbuhannya, sebab kadmium sangat beracun bagi manusia. Keracunan akut yang disebabkan kadmium akan berpengaruh terhadap gejala gasterointestial dan penyakit ginjal. Gejala klinis keracunan kadmium sangat mirip dengan penyakit glomerulonephiritis biasa. Hanya pada fase lanjut dari keracunan kadmium ditemukan pelunakan dan fraktur (patah) tulang punggung yang multipel. Di Jepang sakit pinggang ini dikenal sebagai penyakit "Itai-Itai disease". Gejalanya adalah sakit pinggang, patah tulang, tekanan darah tinggi, kerusakan ginjal, gejala seperti influenza,dan sterilitas pada laki-laki.

4. Sianida $\left(\mathrm{CN}^{-}\right)$

Bekas penambangan mengalami perubahan akibat tereksposnya lapisan batuan yang tersusun atas senyawa sulfida. Limbah pencucian batu bara juga ditemukan pada zat organik dalam perairan tambang batu bara mengalami pembusukan dan menimbulkan bau hasil penguraian zat organik dan senyawa lainnya seperti sulfida. Sulfida yang berada dalam kolam tambang batu bara berasal dari proses pembusukan zat organik berupa hidrogen sulfida $\left(\mathrm{H}_{2} \mathrm{~S}\right)$ yang diproduksi oleh mikroorganisme pembusuk dari zat organik yang bersifat racun terhadap ganggang dan mikroorganisme lainnya (Margareth, 2009). Zat organik hasil pembusukkan akan menimbulkan pencemaran udara dan bau. Sulfida bersifat korosif dalam bentuk hidrogen sulfida yang menyebabkan masalah di lingkungan (Vaiopoulou, 2005).

5. Nitrit $\left(\mathrm{NO}_{2}\right)$

Nitrit $\left(\mathrm{NO}_{2}\right)$, keberadaan nitrit menggambarkan berlangsungnya proses biologis perombakan bahan organik di perairan, dimana nitrogen dalam bentuk ammonia dirombak oleh bakteri nitrosomonas menjadi nitrit. Kadar nitrit yang tinggi dapat menyebabkan kekebalan tubuh (imunitas) organisme menurun sehingga organisme gampang terinfeksi penyakit. Kisaran nilai nitrit ini masih berada pada batas yang diperbolehkan berdasarkan baku mutu yang ditetapkan. Menurut hasil penelitian yang dilakukan oleh Wang et al. (2004), kadar nitrit yang tinggi dapat mengganggu keseimbangan antara antioksidan dan prooksidan pada udang Macrobrium nipponense. Selain itu nitrit juga dapat bereaksi dengan hemoglobin yang menyebabkan terbentuknya methemoglobin sehingga darah tidak dapat mengikat dan mentrasport oksigen ke tissue (jaringan tubuh).

\section{METODE PENELITIAN}

\subsection{Pengambilan sampel}

Sampel air asam tambang bekas kolam batu bara diambil pada PT. MIFA Bersaudara pada dua titik pengambilan sampel. Titik pertama pada inlet, sampel inlet merupakan limbah cair yang akan memasuki kolam penampungan pengolahan limbah. Titik kedua pada outlet adalah sampel yang siap dibuang ke sungai yang telah mendapatkan perlakuan pengolahan limbah dengan penambahan dolomit sebagai mineral penetral.

\subsection{Penanganan Sampel}

Sampel yang telah diambil diuji $\mathrm{pH}$ dan Total Suspended Solid (TSS). Penentuan TSS dengan metoda gravimetri. Sampel untuk analisis logam diawetkan dengan penambahan $\mathrm{HNO}_{3}$ pekat sampai $\mathrm{pH}<2$.

\subsection{Prosedur penelitian}

Untuk menentukan konsentrasi $\mathrm{Fe}, \mathrm{Mn}$ dan $\mathrm{Cd}$ digunakan SSA, Fe pada panjang gelombang 280,50 nm. Untuk Mn pada panjang gelombang $259,50 \mathrm{~nm}$ sedangkan untuk Cd pada panjang gelombang 228,80 nm.

Untuk analisis sianida, sebanyak $10 \mathrm{~mL}$ sampel ditambahkan $5 \mathrm{~mL}$ asam tartarat $5 \%$, kemudian ditambahkan $\mathrm{Na}_{2} \mathrm{CO}_{3} \quad 8 \%$ dan ditambahkan $5 \mathrm{~mL}$ asam pikrat $1 \%$. Campuran dipanaskan dalam penangas air mendidih selama 5 menit. Serapannya diukur pada panjang gelombang $520 \mathrm{~nm}$.

Untuk analisis nitrit, sebanyak $50 \mathrm{~mL}$ sampel ditambahkan $1 \mathrm{~mL}$ sulfanilamid dan dibiarkan selama 2-8 menit kemudian ditambahkan $1 \mathrm{~mL}$ NED-dihidroklorida. 
Proses reaksi dibiarkann sampai tercapai waktu kestabilan warna dan diukur serapannya menggunakan spektrofotometri pada panjang gelombang $543 \mathrm{~nm}$.

\section{HASIL DAN PEMBAHASAN}

Hasil analisis bahan pencemar pada inlet dan outlet kolam penampungan limbah cair pencucian batu bara yang diambil pada tanggal 5 Februari 2018 dan dapat dilihat pada tabel 1 .

Tabel 1. Analisis pada inlet dan outlet kolam limbah cair batu bara

\begin{tabular}{lllll}
\hline \multirow{2}{*}{ Parameter } & \multirow{2}{*}{ Satuan } & \multicolumn{2}{c}{ Sampel } & \multirow{2}{*}{ Baku Mutu } \\
\cline { 3 - 4 } & & SI & S0 & $6-9$ \\
$\mathrm{pH}$ & - & 4,50 & 6,0 & \\
$\mathrm{TSS}$ & $(\mathrm{mg} / \mathrm{L})$ & 376 & 272 & $7^{*}$ \\
$\mathrm{Fe}$ & $(\mathrm{mg} / \mathrm{L})$ & 8,24 & 3,03 & $4^{*}$ \\
$\mathrm{Mn}$ & $(\mathrm{mg} / \mathrm{L})$ & 0,223 & 0,189 & $0,1^{* *}$ \\
$\mathrm{Cd}$ & $(\mathrm{mg} / \mathrm{L})$ & $<0,01$ & $<0,01$ & $3^{* *}$ \\
$\mathrm{NO}_{2}^{-}$ & $(\mathrm{mg} / \mathrm{L})$ & 0,034 & 0,016 & $0,5^{* *}$ \\
$\mathrm{CN}^{-}$ & $(\mathrm{mg} / \mathrm{L})$ & 0,321 & TTD & \\
\hline
\end{tabular}

Ket. : SI : Sampel limbah sebelum pencucian batu bara pada kolam inlet

S0 : Sampel limbah cair pencucian batu bara pada kolam outlet

*: Baku mutu air limbah penambangan batu bara berdasarkan Keputusan Menteri Negara Lingkungan Hidup No. 113 Tahun 2003

**: Baku mutu limbah cair bagi kegiatan industri berdasarkan Keputusan Menteri Negara Lingkungan Hidup no. Kep-51/menlh/10/1995

Nilai $\mathrm{pH}$ yang terukur pada sampel inlet 4,5. Nilai $\mathrm{pH}$ yang asam disebabkan oleh pengupasan tanah penutup, penggalian batu bara, serta waste material yang menyebabkan tersingkapnya tanah/batuan yang mengandung mineral sulfida, antara lain berupa Pirit (Pyrite) dan Markasit (Marcasite). Mineral sulfida tersebut selanjutnya bereaksi dengan oksidan dan air membentuk air asam tambang: $2 \mathrm{FeS}_{2}+7 \mathrm{O}_{2}+2 \mathrm{H}_{2} \mathrm{O} \rightarrow 2 \mathrm{Fe}^{2+}+4 \mathrm{SO}_{4}+4 \mathrm{H}^{+}$

Dengan demikian, selain dicirikan oleh $\mathrm{pH}$ yang rendah, air asam tambang juga akan mengandung logam-logam dengan konsentrasi tinggi hal ini, sejalan dengan hasil analisis logam pada inlet jauh lebih besar konsentrasi dibandingkan outlet, sehingga dapat berakibat buruk pada kesehatan lingkungan maupun manusia (Marganingrum, 2010). Nilai $\mathrm{pH}$ yang terukur pada outlet 6,0 yang menunjukkan limbah outlet pHnya lebih besar dari pada limbah inlet. Hal ini disebabkan karena selama penampungan di dalam kolam dilakukan proses pengolahan dengan menambahkan dolomit. Dolomit $\left(\mathrm{CaMg}\left(\mathrm{CO}_{3}\right)_{2}\right)$ bertindak sebagai mineral penetral pada air asam.

$\mathrm{CaMgCO}_{3}{ }^{2-}-+2 \mathrm{H}^{+} \rightarrow \mathrm{Ca}^{2+}+\mathrm{Mg}^{2+}+2 \mathrm{HCO}_{3}$
Proses reaksi tersebut menunjukkan $1 \mathrm{~mol}$ ion dolomit digunakan untuk menetralkan 2 mol ion asam. Hasilnya $\mathrm{pH}$ menjadi netral sesuai dengan baku mutu $\mathrm{pH}$ yang dianjurkan berdasarkan Keputusan Menteri Negara Lingkungan Hidup No. 113 Tahun 2003 adalah 6-9. Dalam penelitian Ridinata (2012), bahwa penambangan batu bara mempengaruhi badan sungai (hulu-hilir sungai) sehingga $\mathrm{pH}$ air cenderung asam. Kondisi ini menunjukkan bahwa terjadi suplai substrat (mineral sulfida) sebagai pemicu terbentuknya air asam tambang yang menyebabkan naiknya keasaman air di sepanjang aliran sungai. Proses penetralan air asam ini juga dapat mengendapkan logamlogam terlarut, hal ini dapat terlihat pada berkurangnya konsentrasi logam $\mathrm{Fe}$, Mn dan Cd pada outlet.

Hasil uji parameter Total Suspended Solid (TSS) yang terukur pada inlet sebesar $376 \mathrm{mg} / \mathrm{L}$ dan $272 \mathrm{mg} / \mathrm{L}$ pada outlet. Fenomena ini menunjukkan telah terjadi pengendapan selama proses pengolahan air limbah. Jika dibandingkan Keputusan Menteri Lingkungan Hidup No. 113 Tahun 2003, yaitu $400 \mathrm{mg} / \mathrm{L}$ ternyata limbah outlet sesuai dengan 
nilai baku mutu. Sehingga ini akan memberikan tingkat pengurangan pencemaran TSS pada badan perairan lebih rendah. Hal ini berdampak pada pengurangan kekeruhan pada badan air sungai dan kemampuan ikan dan organisme air lainnya dalam memperoleh makanan dan meningkatkan kemampuan tanaman air melakukan fotosintesis.

\section{Analisis parameter $e x$-situ}

Penelitian sebelumnya yang dilakukan oleh Ridinata (2012), telah menganalisis sumber yang belum dicemari oleh limbah cair hasil pencucian batu bara. Pada cuaca hujan dan panas kandungan logam $\mathrm{Mn}$ pada air permukaan sungai yang ada di sekitar tambang batu bara tidak melewati nilai ambang batas baku mutu kualitas air.

Hasil analisis logam kandungan Fe pada inlet kolam tambang batu bara di Aceh Barat mencapai 8,24 $\mathrm{mg} / \mathrm{L}$. Hal ini menunjukkan bahwa kandungan logam $\mathrm{Fe}$ melebih batas Baku Mutu Air limbah penambangan batu bara berdasarkan Keputusan Menteri Negara Lingkungan Hidup No. 113 Tahun 2003. Tingginya kandungan logam $\mathrm{Fe}$ pada limbah air asam tambang batu bara yang dihasilkan dipengaruhi logam $\mathrm{Fe}$ merupakan komposisi dari kandungan batu bara yang terkelupas. Air asam tambang dicirikan dengan rendahnya $\mathrm{pH}$ dan tingginya senyawa logam tertentu seperti besi $(\mathrm{Fe})$, mangan $(\mathrm{Mn})$, kadmium $(\mathrm{Cd})$, sulfat dan pyrite merupakan senyawa yang umum dijumpai di lokasi pertambangan.

Tingginya kandungan cemaran $\mathrm{Cd}$ berasal dari tanah karena kisaran $\mathrm{Cd}$ tersedia pada tanah tanpa diberi kontaminan dan diberi kapur dolomit berkisar dari 0,0750-0,0966 mg/kg (Susana, 2011). Tingginya kandungan Mn pada limbah yang dihasilkan disebabkan karena logam Mn merupakan komposisi dari batu bara itu sendiri dengan nilai kandungan Mn pada batu bara adalah $46 \mathrm{mg} / \mathrm{kg}$ (Tripathi, 2003). Akan tetapi kandungan Mn yang terukur pada outlet $0,189 \mathrm{mg} / \mathrm{L}$ tidak melebihi nilai ambang batas yang ditentukan Keputusan Menteri Lingkungan Hidup No. 113 Tahun 2003, yaitu $4 \mathrm{mg} / \mathrm{L}$.

Analisis kandungan $\mathrm{Cd}$ pada inlet $<0,01$ $\mathrm{mg} / \mathrm{L}$ dan kandungan $\mathrm{Cd}$ pada outlet $<0,01$ $\mathrm{mg} / \mathrm{L}$, kedua sampel ini menunjukkan sesuai dengan baku mutu yang telah ditentukan Keputusan Menteri Negara Lingkungan Hidup no. 51 Tahun 1995 yaitu $0,1 \mathrm{mg} / \mathrm{L}$. Kandungan nitrit dan sianida yang terukur pada sampel sangat rendah, bahkan untuk sianida pada sampel outlet tidak terdetaksi. Pada baku mutu limbah industri nitrit dan sianida termasuk dalam limbah pencemaran akan tetapi pada industri batu bara nitrit dan sianida tidak dipakai, oleh karena itu kandungannya sangat kecil sekali. Keberadaan nitrit dan sianida kemungkinan berasal dari tanah.

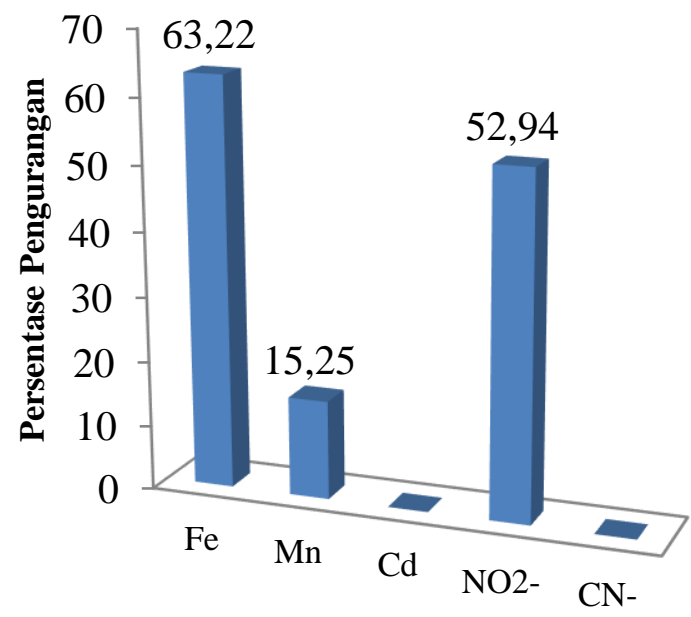

- Persentase Pengurangan

Parameter Kimia 
Pada PT. Mifa Bersaudara menggunakan dolomit sebagai mineral penetral. Dolomit sejenis kapur yang digunakan dapat menaikkan nilai $\mathrm{pH}$ air asam, dengan kenaikan $\mathrm{pH}$ maka kelarutan logam yang terkandung pada air limbah kelarutannya akan berkurang sehingga konsentrasi logam $\mathrm{Fe}$, $\mathrm{Mn}$ dan $\mathrm{Cd}$ pun menurun. Untuk efisiensi dari pengolahan limbah air asam tambang batu bara yang dilakukan PT. Mifa Bersaudara dapat dilihat dari nilai persentase pengurangan yang didapat. Nilai persentase pengurangan tertinggi terlihat pada logam $\mathrm{Fe}$ yaitu 63,22 \%, sedangkan nitrit 52,94\% dan Mn 15,086\%. Instalasi Pengolahan Air Limbah (IPAL) perlu dilakukan oleh pihak industri tambang batu bara.

Pada PT Mifa Bersaudara masih menggunakan dolomit sebagai mineral penetral dengan perbandingan 100 liter air asam tambang : 50 gram kapur dolomit. Dolomit sejenis kapur yang digunakan dapat menaikkan nilai $\mathrm{pH}$ air asam tambang batu bara. sebagai adsorben yang dianggap lebih efisien untuk mengurangi kadar logam $\mathrm{Fe}$ dengan nilai persentase pengurangan tertinggi. Untuk $\mathrm{NO}_{2}$ memiliki nilai persentase pengurangan 52,94\%. Ion $\mathrm{NO}_{2}$ membentuk ikatan dengan logam yang ada pada struktur senyawa dolomit dalam jumlah terbatas (lebih sedikit). Nilai persentase pengurangan untuk Fe lebih tinggi dibandingkan dengan $\mathrm{Mn}$, hal ini disebabkan kelarutan ion $\mathrm{Fe}$ lebih kecil dibandingkan ion $\mathrm{Mn}$ dan ion $\mathrm{Cd}$.

Selain akibat dari kenaikan $\mathrm{pH}$, berkurangnya konsentrasi logam dalam air limbah air asam tambang batu bara diakibatkan oleh terjadinya proses reaksi pertukaran kation. Di mana $\mathrm{Fe}$ dan $\mathrm{Mn}$ yang cenderung lebih bersifat positif dibandingkan $\mathrm{Ca}$ dan $\mathrm{Mg}$, karena memiliki jari-jari atom yang lebih kecil. Hal ini menyebabkan dolomit memiliki ketertarikan untuk lebih cendrung mengadsorbsi $\mathrm{Fe}$ dan $\mathrm{Mn}$ pada struktur dolomit.

\section{KESIMPULAN DAN SARAN}

\subsection{Kesimpulan}

Dari hasil analisis logam pada inlet dan outlet pada kolam penampungan limbah cair hasil pencucian batu bara, maka dapat disimpulkan :

1. Kadar logam berat ion besi, ion mangan, ion kadmium, sianida dan nitrit pada inlet kolam penampungan limbah pencucian batu bara sebesar $8,24 \mathrm{mg} / \mathrm{L} ; 0,223 \mathrm{mg} / \mathrm{L}$; $<0,01 \mathrm{mg} / \mathrm{L} ; 0,034 \mathrm{mg} / \mathrm{L}$; dan $0,321 \mathrm{mg} / \mathrm{L}$.

2. Kadar logam berat ion besi, ion mangan, ion kadmium, sianida dan nitrit pada outlet kolam penampungan limbah pencucian batu bara sebesar 3,03 mg/l; $0,189 \mathrm{mg} / \mathrm{l} ;<0,01 \mathrm{mg} / \mathrm{l} ; 0,016 \mathrm{mg} / \mathrm{l}$; dan tidak terdeteksi.

3. Pengolahan air asam tambang batu bara yang dilakukan PT. Mifa Bersaudara dengan metoda menggunakan dolomit sebagai absorben dengan perbandingan 100 liter limbah cair asam tambang batu bara dan 50 gram kapur dolomit. hasil pembubuhan ini belum optimum untuk mengurangi kadar kadar logam berat $\mathrm{Fe}$, Mn dan Cd .

\subsection{Saran}

Hasil analisis logam (Mn, Fe, Cd), sianida dan nitrit hasil pengolahan air asam tambang batu bara di Aceh Barat menggunakan proses pembubuhan bahan kimia dengan pemberian kapur dolomit yang tidak sesuai takaran akan menyebabkan pencemaran lingkungan khususnya ekosistem perairan sehingga diperlukan penelitian lanjutan dengan perbandingan dan perlakuan dengan bahan lain yang ramah lingkungan..

\section{DAFTAR PUSTAKA}

Dimkic, Heinz-Jurgen, Michael. 2008. Groundwater Management in Large River Basin. Iwa Publishing. London

Dinas Pertambangan dan Energi Kabupaten Kuantan Singingi. 2008. Pemberian Kuasa Pertambangan Ekspolrasi kepada PT. Tri Bakti Sarimas. Pemerintah Kabupaten Kuantan Singingi.

Effendi, H. 2003. Telaah Kualitas Air. Penerbit Kanisius. Yogyakarta.

Kementerian Energi dan Sumberdaya Mineral, 2012. Hand Book of Energy and Economic Statistics of Indonesia 2012. 
Jakarta: Pusat Data dan Informasi Kementerian Energi dan Sumberdaya Mineral (PUSDATIN ESDM).

JICA : Water Supply Engineering Vol. I. Edited by Japan Water Work Association. 1990

Keputusan Menteri Lingkungan Hidup No. 113 Tahun 2003 Tentang Baku Mutu Limbah Cair Penambangan Batubara.

Keputusan Menteri Negara Lingkungan Hidup Nomor : Kep-51/Menlh/10/1995 Tentang Baku Mutu Limbah Cair Bagi Kegiatan Industri

Kiswanto, Heru Susanto, Sudarno. 2018. Karakteristik Air Asam Batubara Di Kolam Bekas Tambang Batubara PT. Bukit Asam (PTBA). Seminar dan Konferensi Nasional IDEC 2018 Surakarta, 7-8 Mei 2018.ISSN: 2579-6429

Marganingrum, D. 2010.Pencemaran air dan tanah di kawasan pertambangan batubara di PT. Berau Coal, Kalimantan Timur. Jurnal Riset Geologi dan Pertambangan 20: 11-20.

Margareth. E. K. Purba. 2009. Analisa Kadar Total Suspended Solid (TSS), Amoniak (NH3), Sianida (CN-) dan Sulfida (S2-) Pada Limbah Cair Bapedaldasu. Medan: Departemen Kimia Program Studi
Diploma-3 Kimia Analis Fakultas Matematika dan Ilmu Pengetahuan Alam Universitas Sumatera Utara.

Ridinata, A. 2012. Analisis Kontribusi Logam $(P b, M n)$, Nitrat dan Sulfat Dari Limbah Tambang Batubara pada Badan Air Sungai Pendulangan Desa Pangkalan Kuansing. Skripsi. Jurusan Kimia FMIPA-UR, Pekanbaru.

Said Nusa Idaman. 2005. Metoda Penghilangan Zat Besi Dan Mangan Di Dalam Penyediaan Air Minum Domestik. JAI Vol. 1 , No.3 page . 239-250.

Susena, R. 2011. Ketersediaan Cd, gejala toksisitas dan pertumbuhan 3 spesies brassicaceae pada media gambut yang dikontaminasi kadmium (cd). Jurnal tek. perkebunan \& psdl. 1: 9-16.

Tripathi, S. M. 2003. Human Ecology and Social Consciousness. Hard Bourd English. ISBN-13 978-8187746751.

Vaiopoulou, Eleni., Melidis, Paris.,Aivasidis, Alexander. 2005. Sulfide Removal in Wastewater from Petrochemical Industries by Autotropic Denitrification. Journal of Water Research 29,4101-4109.

Wang, Y., Xia H., Fu, J. Sheng, G. 2004. Science of the Total Environment 328 (2004)

195-206 